\title{
Beyond the Normal and the Pathological: Recent Literature on Georges Canguilhem
}

Stefanos Geroulanos

Braunstein, Jean-François (éd.), Canguilhem. Histoire des sciences et politique du vivant (Paris 2007)

Daled, Pierre F. (éd.), Alentour de Canguilhem: L'envers de la raison (Paris 2009)

Fagot-Largeault, Anne/Claude Debru/Michel Morange (dir.)/Hee-Jin Han (éd.), Philosophie et médecine en hommage à Georges Canguilhem (Paris 2008)

Le Blanc, Guillaume, Les maladies de l'homme normal (Paris 2008)

Lecourt, Dominique, Georges Canguilhem (Paris 2008)

Keywords: Georges Canguilhem; history and philosophy of medicine; history and philosophy of life sciences

By the time of his death in 1995, Georges Canguilhem had become a highly respected philosopher of biology and medicine and a principal figure in the French tradition of historical epistemology. In France he was known as a thinker in the traditions of Gaston Bachelard and Henri Bergson and, though he founded no school, as a father figure for generations of scholars, including some of the most influential and interesting figures working in philosophy of science, sociology, and the history of thought - among them Michel Foucault, François Dagognet, Louis Althusser, François Delaporte, Pierre Bourdieu, Dominique Lecourt, and even Gilles Deleuze. He was at different stages of his life in explicit conversation with important contemporaries, among them François Jacob, Jean Hyppolite, Jean Cavaillès, Kurt Goldstein, and René Leriche. In America around that time one had only begun translating his work - Ideology and Rationality in the History of the Life Sciences was published in 1990, and The Normal and the Pathological was re-printed by Zone Books in 1991 from a 1978 edition by Springer - and he was prin-

Stefanos Geroulanos, Department of History, New York University, 53 Washington Square South, New York, NY 10012-1098 (sgeroulanos@gmail.com). 
cipally known as a figure that Michel Foucault credited with influencing and supporting him and the generation of the 1960s ${ }^{1}$.

Some fifteen years later, it is fair to say that the study of Canguilhem's work has reached a critical stage and is on its way to becoming a basis for a new generation of scholarship. Appropriately enough, this stage is also quite confusing. In some respects Canguilhem is entering the pantheon of French thought: books on him are proliferating, with at least six published during the last year alone in France, while the Librairie philosophique J. Vrin is preparing a "complete works" series that would include even his earliest and explicitly political writings and that would place him finally among the major authors of twentieth-century French thought. The Centre Georges Canguilhem in Paris publishes regularly collections of essays at once indebted to, and furthering Canguilhem's thought and approach. As a method and rubric, historical epistemology is practiced - and usually with explicit reference to Canguilhem, by an array of established and exciting scholars, among them Lorraine Daston, Ian Hacking, and Arnold Davidson ${ }^{2}$.

In other respects, one wonders whether the rising critical interest in Canguilhem among philosophers of science, anthropologists, and humanists can break through the constraints of the earlier stages of his reception especially in America - or escape the fate of someone like Bachelard, whose work may have defined that of Thomas Kuhn and others, but whose originality and significance has long been languishing. There is at present no definitive study of Canguilhem's place in French intellectual history, and in the Englishspeaking academic world close studies of Canguilhem's understanding of history, biology, and medicine are occasional. Indeed, and particularly in the English-speaking academic world, the hard if astonishing fact is that Canguilhem remains known almost entirely for The Normal and the Pathological, the easiest among his books to recuperate into medical anthropology and the one most resonant with the Foucauldian wave in the humanities. ${ }^{3}$. Over the past few years, new translations into English have started to appear ${ }^{4}$, yet no man-

1 Foucault's often-quoted homage to Canguilhem can be found in Michel Foucault's "Introduction" to The Normal and the Pathological (New York 1991) 7-24.

2 Arnold I. Davidson, The Emergence of Sexuality (Cambridge 2001). Ian Hacking, Historical Ontology (Cambridge 2002). Lorraine Daston/Peter Galison, Objectivity (New York 2008).

3 Like many others, Jan Goldstein has noted this as a prime goal of publications of Canguilhem's work at the dusk of his life, and with specific reference to $A$ Vital Rationalist: Selected Writings of Georges Canguilhem, edited by François Delaporte, translated by Arthur Goldhammer (New York 1995), in his review in Isis 86:1 (March 1995) 84f.

4 Georges Canguilhem, Knowledge of Life, translated by St. Geroulanos and D. Ginsburg, edited by P. Marrati and T. Meyers (New York 2008); "Health: Crude Concept and Philosophical Question", translated by St. Geroulanos and T. Meyers, Public Culture 20:3 (Fall 2008); "Diseases", in: R. Baxstrom/T. Meyers (eds.), Anthropologies (Baltimore 2008); "Is there a Pedagogy of Healing?", Umbr(a): Incurable (Buffalo, NY 2005). 
uscript-length publications on Canguilhem have appeared, only one journal issue dating to $1998^{5}$. In France, meanwhile, the three different institutions named after him are fighting bitter custody battles over his legacy - battles that have apparently affected even the Euvres completes project.

Recent publications on Canguilhem are thus of considerable interest in evaluating the importance, potential, and consequences of his legacy for studies in medical anthropology, the history of ideas, the philosophy of medicine and theories of notions of life. The present essay reviews and addresses five recent French works that offer a broad map of Canguilhem's work and influence: Dominique Lecourt's Georges Canguilhem (PUF 2008), Guillaume Le Blanc's Les maladies de l'homme normal (Vrin 2008), and three edited volumes: Jean-François Braunstein's Canguilhem. Histoire des sciences et politique du vivant (PUF 2007), a volume called Philosophie et médecine en hommage à Georges Canguilhem edited by Hee-Jin Han (Vrin 2008), and also Alentour de Canguilhem: L'envers de la raison, edited by Pierre F. Daled (Vrin 2009). Before engaging with these works, a few words on Canguilhem's own oeuvre are necessary.

Canguilhem's five central books, which encompass the bulk of his philosophical, historical, and critical oeuvre, are: Le normal et le pathologique (The Normal and the Pathological,1943 / second, modified edition: 1968), La formation du concept de réflexe aux XVII et XVIII siècles (The Formation of the Concept of Reflex in the 17th and 18th Centuries, 1955), La connaissance de la vie (Knowledge of Life, 1952 / second, modified edition: 1965), Idéologie et rationalité dans l'histoire des sciences de la vie (Ideology and Rationality in the History of the Life Sciences, 1977), and Etudes d'histoire et de philosophie des sciences (Studies in the History and Philosophy of the Sciences, 1990) ${ }^{6}$. Only the first two are books, properly speaking; the latter three are collections of essays and talks, though Connaissance de la vie and Idéologie et rationalité each engage with a particular problem and have rather clear goals and philosophical targets. As noted already, Canguilhem is best known for the first of these, translated as The Normal and the Pathological. That work came at a crucial point in the history of medicine and forcefully articulated a concern that was to some degree felt across much of medical thought; namely, that medicine, biology, and physiology rely on statistical

5 Economy and Society 27:2-3 (May 1998). One should also note the special section in Philosophy, Psychiatry, \& Psychology 9:4 (Dec. 2002) 299-318.

6 Subsequent references are to the following editions: La formation du concept de réflexe aux XVII e et XVIII ${ }^{e}$ siècles (Paris 1955); Knowledge of Life (New York 2008); Etudes d'histoire et de philosophie des sciences (Paris $\left.{ }^{5} 1989\right)$; Idéologie et rationalité dans l'histoire des sciences de la vie (Paris $\left.{ }^{2} 1993\right)$. 
norms that hamper rather than aid not only diagnosis and treatment but the understanding of the sick man's relation to society and the treatment itself. Canguilhem worked from a perspective directly influenced by the surgeon René Leriche and the German neurologist Kurt Goldstein. However, his claim that a normativity based on statistically engendered normality fails to explain the complexity of physiological disorders and the patient's relation to his/her environment and to treatment closely related to contemporary physicians and physiologists - from Walter B. Cannon through Hans Selye to embryology, behavior physiology, and endocrinology. It also reflected and addressed the work of a new generation of philosophers of science in France (such as Alexandre Koyré, Jean Cavaillès and Gaston Bachelard) who had questioned the status traditionally accorded to experimentation and the fantasy of positivism that they saw as defining much contemporary science and scientific thought. The second book and the one that firmly established Canguilhem's system was La connaissance de la vie (Knowledge of Life). It expanded Canguilhem's focus toward the history of biology and it also turned the epistemological focus toward the interplay of philosophy, modern science, and conceptual history. And utilizing a perspective much influenced by Henri Bergson's Creative Evolution, Canguilhem at length presented on the dual irreducibility of "knowledge" and "life" to one another, addressing the political implications of cell theory, the imperiousness and insufficiency of the mechanist legacy, and the relationship between an organism and its milieu. Writing on the eve of the cybernetic and DNA revolutions that would offer a new paradigm for biological thought, Canguilhem used his conceptual histories to argue for a kind of negative vitalism: while rejecting vitalism, he refused any reduction of life to a sum of mere mechanistic physico-chemical principles. Moreover, his critique of mechanism would become a premise and focal point of his later writings on the reflex and on behaviorism, and it would serve as an exemplar of what Canguilhem would refer to by the term "scientific ideology"7.

The first peak of Canguilhem's influence came in the 1960s and related in large part to the various phenomenological and late marxist debates on science. As has been amply documented, certain strands of French phenomenology took a scientific turn in the 1950s, thanks not only to Merleau-Ponty's persistent engagement with Gestalt psychology and quantum mechanics in La Nature and elsewhere, but also the broader reception of Husserl's Die Krisis der europäischen Wissenschaften und die transzendentale Phänomenologie (The Crisis of the European Sciences), the writings of Suzanne

7 See his “Qu'est-ce qu'une idéologie scientifique?", in: Idéologie et rationalité dans l'histoire des sciences de la vie (1977). 
Bachelard, Paul Ricœur, and others ${ }^{8}$. It is clear that Althusser and Althusserians - but also Bourdieu and his school of sociology - were attracted to Canguilhem's writing because of its rejection of positivism, its distance from Hegel, and its construction of a system for which the formulation and validation of scientific truths was always anchored on social context, conceptual history, and a system for producing its own truths. That is to say, while Canguilhem was at best ironic toward Soviet science, he offered a platform from which to consider scientific engagements in the West as much as in the East as tied to - and indeed capable of formulating their own - particular ideologies' 9 . Certainly, the conversation between The Normal and the Pathological and Foucault's critiques of rationalism in Histoire de la folie (History of Madness) and of the clinical gaze in Naissance de la clinique (Birth of the Clinic) also furthered Canguilhem's influence on the world surrounding structuralism ${ }^{10}$. It also offered the now classic route for the understanding of Canguilhem - to paraphrase Pierre Macherey, "from Canguilhem to Canguilhem by way of Foucault"11. A mixture of these two trends account for the early stage of broad scholarly interest in Canguilhem in the United States as well, where many of the figures he wrote on at length (Auguste Comte, Claude Bernard, François-Joseph-Victor Broussais) and had used as starting points for philosophical claims, do not form part of the canon in the same way that they do in France ${ }^{12}$.

A further figure of Canguilhem has been of value to medical anthropology and the philosophy of biology, and has emerged with the above movements. Namely, that of Canguilhem as a critic of the genetic paradigm's totalizing claims; as a philosopher engaged with the question of the value of the living human being and invested in defending it against medical rationalization; as a thinker for whom individuality signifies irreducible novelty, a particular relation to the milieu, and difference from other beings that would be structurally the same $\mathrm{e}^{13}$. This figure has largely had a complementary value to the dominant one discussed above, yet it is significant to point to it here, as the "genetic program" paradigm has loosened since the 1970s and as various sorts

8 My thanks to Edward Baring for explaining to me Suzanne Bachelard's role in this movement.

9 See his Knowledge of Life (2008) 54, 115.

10 Michel Foucault, Histoire de la folie (Paris 1961), Naissance de la clinique (Paris 1963).

11 Pierre Macherey, De Canguilhem à Foucault (Paris 2009).

12 The extensive focus on the problem of normativity and the theorization of scientific ideology is echoed as a problem by Henning Schmidgen, "Georges Canguilhem et les discours allemands", in: Fagot-Largeault/Debru/Morange/Han 2008, 50.

13 For a useful treatment of Canguilhem on individuality, see Jean Gayon, "The Concept of Individuality in Canguilhem's Philosophy of Biology", Journal of the History of Biology 31 (1998) 305-325. 
of neo-Lamarckian (for lack of a better term) tendencies have emerged. The critical and philosophical potential of this approach appears particularly significant in this context, because Canguilhem's understanding of individuality places him squarely in a perhaps unlikely context of early postwar thought of thinkers like Theodor Adorno, Hannah Arendt, for whom a new thinking of the individual is necessary for its defense against totalizing systems in politics and philosophy. This is precisely the achievement of a number of studies, notably in the Etudes d'histoire et de philosophie des sciences, which includes his famous and important critique of psychology ("Qu'est-ce que la psychologie?") and the posthumous collection Ecrits sur la médecine, which brings together later studies of health and patienthood.

This second kind of emphasis has become increasingly forceful in more recent years, and it is in large part this attention to individuality and life that foregrounds the books under discussion here. It is perhaps a result of a broader shift of focus: a certain sunset of figures like Pierre Bourdieu and Louis Althusser, a return of Henri Bergson as a major figure in French twentieth-century thought, a strengthening sense of Gilles Deleuze as an inheritor of Bergson, and the evolution of the reception of Foucault in the United States. Thanks to this shift, possible if seemingly unlikely comparisons of Canguilhem to philosophers like Adorno, Derrida, Wittgenstein, and Butler are becoming clearer to grasp and useful for an understanding of the links of certain of the concepts he develops to contemporaries. Thanks to the same shift, it is becoming increasingly possible to consider Canguilhem as a philosopher of political and (perhaps even despite himself) ethical questions.

Dominique Lecourt's intellectual biography Georges Canguilhem is a useful if ultimately still rather cursory examination of Canguilhem's participation in philosophy, education, and politics, from his earliest writings in the 1930s through to his last writings. By tracking Canguilhem's philosophical and pedagogical contributions and by grounding them on the course of his early investments in pacifism (in the early 1930s), antifascism (in the later 1930s), and the résistance, Lecourt succeeds in giving a unified view of Canguilhem's writings on philosophy, history of science, and medicine, as well as in effectively re-introducing him as an interwar and mid-century intellectual.

Lecourt pays attention to three significant aspects of Canguilhem's path, the first two of which have generally been seen as minor. First, from the beginning of his book, Lecourt gives pride of place to Canguilhem's relationship with the philosopher Alain (he was Alain's protégé until 1934) and sees in him the utility of 1920s thought during his 1930s writings and even for the major Canguilhem works. Over the past few decades, the value of a whole 
generation of philosophers (Lagneau, Brunschvicg, Alain, Benda) has been thoroughly underplayed, in large part because of, first, the phenomenological break with Neo-Kantianism and, second, the radical distance, in both inspiration and argumentation, of thinkers bracketed as structuralist and post-structuralist, from that generation. Lecourt's attention to these thinkers (with whom, it must be noted, the post-war Canguilhem shared precious little in terms of both methodological principles and philosophical aims) helps restore a sense of how their legacy not only influenced his ethics and pedagogical engagement. Indeed, Lecourt here gives a strong impression of how and why Canguilhem has to be seen as a philosophe: how his move from an Alain-influenced pacifism in the early 1930s toward a combative (and noncommunist) anti-fascism in the mid-1930s, his resignation from the university in 1940, and his wartime résistance involvement help influence his philosophical stance toward a new theory of individuality and subjectivity. Lecourt convincingly shows that thanks to the intellectual world of the 1920s, Canguilhem became not just a philosopher but a philosophe, using or centering on his philosophy of medicine to further a political thinking of subjective existence amidst medical, technological, administrative, and political milieus.

Second, Lecourt attends at least as much to the lesser works that criss-cross Canguilhem's oeuvre as he does to the major ones. In his mid-1930s antifascist phase, the young Canguilhem wrote a study of Fascism and the peasants $^{14}$. In 1939, with Claude Planet, he wrote a treatise on logic and ethics ${ }^{15}$ intended for high-school students. In later collections of essays and introductions to other thinkers (Bachelard in the latter's Etudes ${ }^{16}$, Cavaillès in Vie et mort de Jean Cavaillès), Canguilhem would implicitly reorganize their philosophical and personal legacies in relation to his writing, foregrounding both their contributions to philosophy and history of science and the ethics of the intellectual spirit they furthered. Lecourt's attention to these texts gives a much clearer impression of the genealogy Canguilhem helped produce for his own thought - and for critical and historical epistemology as a philosophical genre. It also helps explain politico-philosophical goals that persist in his writing as a whole. From the book with Planet Lecourt quotes:

Invoquer dans les circonstances actuelles [1939] la possibilité d'un arbitrage international, c'est oublier que l'arbitrage, sous forme de diplomatie, de cours internationales de justice, de Société des nations, etc., est une couverture, précaire d'ailleurs, de relations entre forces affrontées. ${ }^{17}$

14 Georges Canguilhem, Le fascisme et les paysans (Cahors 1935).

15 See Lecourt 2008.

16 Gaston Bachelard, Etudes (Paris reprint 2000). Georges Canguilhem, Vie et mort de Jean Cavaillès (Ambialet 1977).

17 Lecourt 2008, 27. 
This mistrust of arbitration and claims to political equality and harmony helps frame Canguilhem's later choices - both his critique of the dependence of a patient on elaborate systems (moral, metaphysical, and pragmatic) concerning health, personal and social, as well as his choice of medicine and modern science as champs, domains in which to consider (and not merely as political) the implications of medical intervention and techno-scientific innovation for subjectivity.

Thus, third, by highlighting Canguilhem's political and educational agenda, Lecourt's book helps re-introduce much of the ethic of Canguilhem's thought, in particular his consistent commitment to the irreducibility of the individual that is constantly undermined by organized, systematic practices. This achievement is central to the new writings on Canguilhem and to the recognition of the theoretical contribution of his writing in its midcentury context, and indicates a particular brand of philosophical modernism that persists into his later engagements and pedagogical presence. (By philosophical modernism I mean that already in The Normal and the Pathological Canguilhem finds himself at a crossroads of modern thought, which he addresses by moving partly against classical subjectivism - which would emphasize the normal, normative construction of the individual -, and at the same time toward a radical, even an-archic individual in his or her irreducible subjectivity.)

It is certainly important that Lecourt manages to be so suggestive in a short intellectual biography. And it is worth noting in passing that the picture Lecourt's approach leaves the reader is nevertheless tentative; though excellent as a general intellectual biography, Georges Canguilhem attends to no unpublished materials and its aim is a still one of introduction as regards Canguilhem the thinker. So in that sense, this effort helps introduce the many projects utilizing or historicizing Canguilhem that are offered in the other recent publications on him and that I would like to center on here.

Among these projects we can discern several: an effort to make more precise the relationship of Canguilhem to his interlocutors - contemporaries, inspirators, and critics; a rethinking of Canguilhem's approach to medical and biological systems of thought, whether contemporary or historically influential; a concern with what remains of his major claims given fifty years of dramatic transformations in medicine and biology; a rethinking of Canguilhem's epistemology of psychology and madness, as well as his role as an influence on Michel Foucault and the anti-psychiatric movement of the 1970s; an interrogation, finally, of Canguilhem's interest in philosophy of values and philosophical anthropology. (In what follows, I will attempt to 
consider the different books separately, but I will make cross-references wherever necessary to highlight these "projects".)

The force of Jean-François Braunstein's edited collection Canguilhem. Histoire des sciences et politique du vivant lies in its successful organization of many of these different concerns. Except for Ian Hacking's contribution on Canguilhem and cyborgs, which was first published in the aforementioned 1998 issue of Economy and Society, the essays are new and address much of the breadth of the current state of study and value of Canguilhem. The organization of this little book plays up a couple of major problems in different clusters of essays: one concerning problems of milieu, rejection of reflex, and individuality (Braunstein, Lecourt); another surrounding the normal and pathological from perspectives influenced by Canguilhem's attention to mechanism and abnormality, cyborgs and monsters (Hacking, Delaporte); yet a third cluster on methodology and historiography (Delaporte, Braunstein, Debru); and a fourth around Canguilhem's particular brand of vitalism and thinking of life (Dagognet, Braunstein, Utaker).

Two essays, by François Dagognet and Dominique Lecourt, open the volume in usefully introducing some of Canguilhem's early concerns that would become persistent motivating forces for his later work as well. François Dagognet addresses Canguilhem's understanding of "life" in relation to efforts to reduce an organism's singularity, a thread followed (and considerably expanded upon) in Jean-François Braunstein's central essay in this volume, which concerns Canguilhem's radical critique of psychology. Dagognet's essay is useful as regards the links between Canguilhem's understanding of life as creativity and his address of problems of the reflex and the milieu. In keeping with his argument in his earlier book Georges Canguilhem: Philosophie de la vie ${ }^{18}$, Dagognet argues that genetics offered Canguilhem a new language for thinking about the living human being, which "consolidated" - rather than changed - his philosophy. Dagognet shows that the prioritization of life as creation and creativity organizes Canguilhem's conceptual rejection of Pavlovian conditioning as well as his distance from mechanist determinations of the organism (e.g. DNA understood as a program for the organism's development and behavior), alternatives that Dagognet indicates Canguilhem rejected as fixist, as eradicating even the possibility of originality in an organism ${ }^{19}$. This particular problem is extended - in a some-

18 François Dagognet, Georges Canguilhem: Philosophie de la vie (Paris 1997).

19 It is nevertheless useful to note that Canguilhem's attitude toward DNA as a kind of mechanism changes over time and that later in his career, he left his seminal essay "Aspects of Vitalism" (in Knowledge of Life) behind as dated. Braunstein notes this in his essay "Deux philosophies de la médecine: Canguilhem et Fleck", in: Fagot-Largeault/Debru/Morange/ Han 2008. 
what different direction - by Braunstein's essay. Addressing both the epistemological and ethical concerns of Canguilhem's famous 1956 lecture "Qu'estce que la psychologie?"20, Braunstein opens to both his book on the history of the reflex and his understanding of the relationship between the living organism and its milieu; here, Canguilhem's signature critique of determinism and reductionism is on full display, as Braunstein treats the interpretations (and intellectual rejections) of Taylorism and Behaviorism as connected to the claims - in Knowledge of Life - that the living human being does not tolerate values forced by a destructive milieu and that in circumstances of health it seeks and works to overcome these ${ }^{21}$. No milieu - psychological included, and here lies the value of the critique of psychology - can eliminate the subject's resistances to such determinist approaches, its tendency to constitute for itself a milieu. And, Canguilhem argues, the need for subjectivity understood as radical refusal and resistance, as difference, meets here with the political and philosophical demand of overcoming the restricted chances offered by any man-made political or technological milieu ${ }^{22}$.

A major movement emerges from here, namely an effort to interpret Canguilhem's vitalism, or rather, his refusal to accept any sort of mechanist or physico-chemical reduction of life. As Hee-Jin Han notes in Philosophie et médecine, Canguilhem's understanding of vitalism itself involved perhaps too much suspicion on his part toward its structure and possibilities and thus resulted in a rather reductive interpretation ${ }^{23}$, yet it is important to note that Canguilhem, in "Aspects of Vitalism" and other essays in Knowledge of Life, as well as in La formation du concept de réflexe, single-handedly restored vitalism's claim to philosophical respectability that the vast majority of contemporary observers saw as both obsolete and irrevocably tainted by Nazism $^{24}$. Braunstein's essay makes the strongest case for understanding Canguilhem's attachment to vitalism, reading in Canguilhem a vitalism premised less on the affirmation of life and more on the consistent refusal political, philosophical, and ethical - to efface life as creativity and absolute originality ${ }^{25}$.

20 Elisabeth Roudinesco has written an eloquent discussion of the lecture in her Philosophy in Turbulent Times (New York 2008) 25-29.

21 Braunstein, "Psychologie et milieu", in: Braunstein 2007, 75, 81, 83.

22 Braunstein, "Psychologie et milieu", in: Braunstein 2007, 89.

23 Han, "Georges Canguilhem et le vitalisme français: remarques sur les 'aspects du vitalisme", in: Fagot-Largeault/Debru/Morange/Han 2008,13-34.

24 See Ernst Cassirer, The Problem of Knowledge (New Haven 1950) 188-216.

25 It is in this sense that Canguilhem's argument can be read as closely related to Hannah Arendt's in The Origins of Totalitarianism, where against totalitarianism Arendt concludes by invoking "natality" - the birth of every new individual human being - as both a sign of what totalitarianism seeks to efface and a mark of what resists it. 
Much of the remainder of the volume centers on possible openings from Canguilhem's writing toward that of others. François Delaporte writes on historical epistemology and offers an attentive way of interpreting the Bachelard-Canguilhem-Foucault line of critical epistemology that Lecourt (among others) has written extensively on ${ }^{26}$. Delaporte traces questions of monstrosity and error in an effort to show Canguilhem and Foucault's effort toward an understanding of truth in history and epistémés ${ }^{27}$. And just as Ian Hacking attempts to read Canguilhem together with Foucault and Donna Haraway (and thus to consider the problem posed by machines and monsters - a concern of other historical epistemologists like Davidson and Daston as well), Arild Utaker's argument reflects and foregrounds another tendency: to consider Canguilhem in the context of recent discussions of ordinary language. Arild Utaker offers a reading of Canguilhem's relation to Wittgenstein and the use of a parallel reading for a critique of cognitive science.

This trend in reading Canguilhem links well to that found in much more elaborate detail in Guillaume Le Blanc's Les maladies de l'homme normal. Le Blanc has established himself as a thinker deeply concerned with the political and intellectual legacy of Canguilhem and Foucault, and it needs to be noted that over the past decade, his writings have been central to the revitalization of Canguilhem's thought in contemporary French philosophy. In his new book, aimed at non-specialists, Le Blanc asks to what degree a thinking of normativity is still possible and desirable, and in what ways it may be overcome for a conception of the human defined in terms of identities that are not reducible to a basking in normality. Le Blanc explicitly aims at a political critique of "normal man" (l'homme normal) ${ }^{28}$ and sees the reductive and violent judgment of normality as the judgment now paramount to all other judgments ${ }^{29}$. The directness of this political argument comes time and again, and compensates for its own repetitiveness and for a certain naiveté that I hope Le Blanc is staging for strategic purposes (as evidenced by, for example, the following passage):

Qu'est-ce alors que l'homme normal si ce n'est une entité abstraite, débarrassée des conflits de normes dans lesquels sont situés les sujets? L'homme normal c'est alors le rêve (cauchemar?) d'une vie dans une seule norme qui la déroule (les normes du travail par exemple) et en laquelle elle s'exhibe, protégée de l'adversité, de ses terreurs, de tout le négatif qui la hante et ne cesse de la hanter, par le liseré homogène d'une norme ou d'un ensemble de normes en laquelle elle se fond pour ne pas avoir à être. ${ }^{30}$

26 Dominique Lecour, Pour une critique de l'épistémologie: Bachelard, Canguilhem, Foucault (Paris 1972).

27 Delaporte, "Foucault, Canguilhem et les monstres", in: Braunstein 2007, 106-8, 111-2.

28 Le Blanc 2008, 7.

29 Le Blanc 2008, 19.

30 Le Blanc 2008, 63. 
Le Blanc thus echoes Canguilhem's quotation from Louis Roule regarding the normal as a "normalized monster" 31 - but with the explicit aim of philosophically exploding the sheer possibility of any norm-based normality. And if Utaker sees Canguilhem as integral to a critique of the cognitive science paradigm that has become so powerful for example to Anglo-American philosophical accounts of the mind problem, Le Blanc's sights are aimed at something broader: he hints at Canguilhem as someone to read with not only Foucault but also Judith Butler, Michel de Certeau, Cornelius Castoriadis and Stanley Cavell - that is, as someone of continuing critical value for a thinking of the every day, of freedom, of homogenizing violence. Of the engagements with Canguilhem considered here, this is still the effort most profoundly tied to The Normal and the Pathological, or rather to the dismantling of this binary that Canguilhem already sought ${ }^{32}$. While serious questions could be asked whether this "normal man" still exists as a philosophical category (whether Le Blanc's use of it as such does not allow for a rather vague generalization of insights derived from thinkers already beyond the normal/abnormal distinction) or whether this normal man is anything less than the strawest of straw men, this book is also the one most clearly able of showing the relevance of Canguilhem for social theory, for a thinking of the every day that would aim beyond the undesirable yet near-inevitable ontological homogeneity.

Edited by Pierre F. Daled, Alentour de Canguilhem: L'envers de la raison takes the engagements of The Normal and the Pathological in a quite different direction. Still invested in a concern centered around Broussais' principle and the theorization of error, this collection considers above all problems of psychiatry. Its starting point for a reading of Canguilhem's thinking on medicine and pathology is the 1960s, especially the explosion of anti-psychiatry in the Western world; at stake is The Normal and the Pathological's status in a history less concerned with normativity itself than with the oppositions to classical normality and its conception of the pathological ${ }^{33}$.

[...] ce volume voudrait esquisser l'histoire d'un éventuel «parti pris» en faveur de l'envers de la raison et donc ainsi de sa possible valorisation, ou, en tout cas, de sa non dévalorisation au sein même de notre normalité rationnelle, à partir du début du $19^{\mathrm{e}}$ siècle et du «principe de Broussais», jusqu'à l'époque de Foucault et de l'antipsychiatrie, en passant par celle de Canguilhem. ${ }^{34}$

31 Canguilhem, Knowledge of Life (2008), 126.

32 For Le Blanc's other books on, or related to, Canguilhem, see: Canguilhem et les normes (Paris 1998), Anthropologie et biologie chez Georges Canguilhem (Paris 2002).

33 Daled 2009, 13.

34 Daled 2009, 15. 
Canguilhem's historical study plays the role of a crux and an umbrella here, as it is through a history of psychological pathology and psychiatry - including questions of dreams and drugs (hashish) - theorizations of the normal are engaged. Two studies in particular on the figure of Jacques-Joseph Moreau de Tours are of significant interest here, extending and complicating Canguilhem's historicization of the normal and expanding Foucault's treatment of Moreau de Tours in Psychiatric Power as the "Claude Bernard of madness" 35 . In a particularly interesting essay, Jacqueline Carroy places her consideration of Moreau de Tours and his contemporaries Alfred Maury and Charles Richet amidst a discussion of drugs, madness, and dreams - asking the role played by practices of self-experimentation and self-observation in the determination of interiority, the understanding of pathology (especially psychological pathology). The same concerns drive Juan Rigoli's essay on Moreau de Tours and "intimate observation" and help not only clarify the relations between psychiatry, philosophical spiritualism, and related problems in the period but also to address the role played in the mid-19th century by (for lack of a better term) altered states of consciousness in the theorization of the soul, of consciousness, of reason - for medical practitioners and philosophers alike. Central to the volume's discussion of normativity, psychology, and value is of course Friedrich Nietzsche, and Daled offers in Alentour de Canguilhem a forceful essay exploring Canguilhem's selfunderstanding as a "nietzschéen sans cartes" ${ }^{36}$. Emphasizing Nietzsche's presence in Canguilhem's interpretation of Bernard, Daled attends to Canguilhem's understanding of health and reason, the persistence of "the normal" as a moral concept, and opens up the question of value and values. This turn is particularly important to the course of the overall argument of the book, notably its careful effort to situate Canguilhem's critique and historicization of medical rationalism.

Further studies in Alentour de Canguilhem center on Canguilhem's contemporaries: Jean-Christophe Coffin's discussion of Henri Ey is particularly helpful in providing both context and specificity to Canguilhem's project, because it considers a figure who, initially sympathetic to Canguilhem's project (and indeed cited by him in The Normal and the Pathological) turned increasingly hostile thanks to Canguilhem's alliance with Foucault. Similarly, Foucault is implicitly addressed in Sven Andersen's essay on Laing and antipsychiatry in the United States (Laing published the American edition of Madness and Civilization). Though anti-psychiatry is not necessarily the con-

35 Michel Foucault, Psychiatric Power (New York 2008) 279. Jacqueline Carroy, "Observation, experimentation et clinique du soi", in: Daled 2009, 58.

36 Daled, "Santé, folie et vérité aux XIX"e et XX" siècles", in: Daled 2009, 137. 
text one would most readily identify Canguilhem's thought with, the book makes it clear that an understanding of the changing status of the concept of the pathological in postwar thought requires and benefits considerably from the comparison.

A further effort to engage with Canguilhem by situating him and finetuning his intellectual force and argument is carried out in Fagot-Largeault, Debru, Morange and Han's Philosophie et médecine en hommage à Georges Canguilhem. Claude Debru introduces the volume, specifically pointing to the persistent attraction of Canguilhem's writing some fifty-plus years after the publication of his major works and the development of genetics and molecular biology which "left behind the qualitative models of physiopathology and brought to discredit vitalist speculations" ${ }^{\prime 37}$. The book centers on the relation of Canguilhem to contemporaries (significantly Ludwik Fleck, by Jean-François Braunstein, but also Karl E. Rothschuh and Pedro Laín Entralgo, by Luìs Montiel), German predecessors (pathologists G. Ricker and G. Herxheimer, by Henning Schmidgen, and also Nietzsche again, by Laurent Cherlonneix), physiology and philosophy (Ali Benmakhlouf and Jean-Claude Dupont), biology and epidemiology (Michel Morange and Elodie Giroux), and on the question of the living and vitalism (Hee-Jin Han, Frédéric Worms, Jean-Gaël Barbara). This volume is more emphatically historical, invested in establishing both the intellectual genealogies that Canguilhem relied on and concerned with offering critiques of excessive expectations.

Within this historical focus the emphasis on the living is crucial. Worms's essay traces Canguilhem's use of the concept of the living and the use of this concept to locate and theorize his major concerns (including that of the normal and the pathological). The need in Canguilhem's thought for a history of the life sciences, Worms writes, comes

[...] aussi, et surtout, parce que l'expérience du vivant ne se résume plus à la santé et à la maladie au sens strictement (et trop facilement sans doute) physiologique ou organique: il s'étend désormais et même prioritairement à la théorie et à la pratique de la connaissance [...] ce n'est pas seulement l'erreur, dans la connaissance, mais aussi l'idéologie et le pouvoir, dans et sur le vivant, qui vont attester, bien loin de leur disparition sous l'effet de l'objectivation des sciences de la vie et sans contredire cette objectivation conceptuelle et scientifique incontestable, de l'extension du normal et du pathologique dans la connaissance du vivant ${ }^{38}$

Worms grounds here from a philosophical point of view the relation of the concept and life that is essential across Canguilhem's thinking and explains

37 Debru, "Introduction", in: Fagot-Largeault/Debru/Morange/Han 2008, 9.

38 Frédéric Worms, "La conception du vivant comme philosophie première",in:Fagot-Largeault/ Debru/Morange/Han 2008, 147, italics his. 
why this use of "the living" does not recoil onto a vitalism of sorts but instead offers the experience of living and the consciousness of living as criteria for any philosophical, political, or scientific systematizations. Jean-Gaël Barbara's study of biology as a knowledge of life in Canguilhem, which attends to the status of biological objects and to Canguilhem's discussion of the tensions in biological theories (mechanism vs. vitalism, etc.), Han's aforementioned essay on Canguilhem and vitalism, and Dupont's essay on Canguilhem's resistance to the reflex effectively deploy this problematic concerning the status of life and knowledge for the living human being. This consideration is also present in Cherlonneix's essay on Nietzsche and Canguilhem with its close readings on questions of sickness - an essay that is worth reading alongside Daled's essay in Alentour de Canguilhem -, and also in Jean-François Braunstein's essay on Canguilhem and Fleck. Given the status of Fleck as a father figure of "social studies of medicine", medical anthropologists and historical epistemologists alike will find Braunstein's treatment particularly useful for its comparative theorization of the two authors' contextualization of theory and knowledge amidst social and conceptual history.

One of the things also indicated in this volume is the pragmatic assumption of a thinking that is close to Canguilhem's in doctor-patient relations, the training of doctors, and the perception of medicine's value. Montiel's essay on Rothschuh and Laín, like the emphasis on the influence of antipsychiatry in Alentour de Canguilhem, offers a sense of both the lens through which Canguilhem's early work is to be seen from an educational perspective and the ways in which the thinking of the abnormal and the pathological has transformed in both the philosophical and the everyday contexts. In Canguilhem. Histoire des sciences et politique du vivant Claude Debru suggests that a particular value can be attached to Canguilhem's work in the context of patients' efforts to contend with therapies, their role in them, and their mortality ${ }^{39}$ - all but offering a Canguilhem that would contribute to a psychological therapeutics or at least a personal engagement with medical subjectivity.

Philosophie et médecine is also more frequently critical than the other books considered here. Morange stages the limitations of The Normal and the Pathological, criticizing its lack of attention to microbiology ${ }^{40}$, holding its main claims as untenable on the basis of then-contemporary biology and

39 Debru, "L'engagement philosophique dans le champ de la médecine", in: Braunstein 2007, 48.

40 Morange, "Retour sur le normal et le pathologique", in: Fagot-Largeault/Debru/Morange/ Han 2008, 159. 
pathology $\mathrm{y}^{41}$, and suggesting that in this writing is to be found a dismissal of medicine's capacity to improve ${ }^{42}$. Elodie Giroux's essay seeks to shield epidemiology and population studies from the possible accusation of ignoring individuality altogether ${ }^{43}$, and as noted earlier, Han critiques in a very interesting fashion the presuppositions in Canguilhem's reading of vitalism. Some of these critiques of Canguilhem's use for epidemiology and conceptions of health today seem to me to be bordering on a weird kind of naïve empiricism when they insist that the $N P$ thesis is rather dated (of course it is!) and caution against its overuse. Yet in the effort to situate Canguilhem as well as render him productive for a new generation of readers, some of the essays in Philosophie et médecine help considerably by criticizing a possible tendency to read too much in Canguilhem; they also help show what is actually significant about Canguilhem's voice and force. In this tendency of critique, together with the movement toward a practice of historical epistemology, and the effort to comes better into view the crux-like presence that Canguilhem constituted vis-à-vis thinkers of previous, contemporary, and following generations - including perhaps the authors writing now.

All in all, then, a major force to be found in these new works is to move Canguilhem beyond the classic frame offered by the discussion of the normal and the pathological. I noted earlier that these collections aim at a series of efforts: to address the relationship of Canguilhem to his interlocutors, to reposition Canguilhem's thought in relation to medical and biological systems of thought, to ask what remains of his major claims, and to ask the status of his epistemology of psychology and madness. In these tasks the works addressed here clearly row the study of Canguilhem to a new shore.

I have also hinted at a somewhat more complex task: to address Canguilhem's place in (and the place in Canguilhem's writings of) a philosophy of values and a philosophical anthropology. Though efforts in this direction are made (notably as regards the question of values, with Daled's exploration of the link to Nietzsche, Han's understanding of the negative ${ }^{44}$, Le Blanc's persistence on the normal, and the attention in Philosophie et médecine on questions of the living), the link of Canguilhem's epistemology to his broad anthropological concerns and to the question of what holds positive value to

41 Morange, "Retour sur le normal et le pathologique", in: Fagot-Largeault/Debru/Morange/ Han 2008, 148. On this point Morange seems to see contemporary changes in pathology as countering - rather than working with - Canguilhem's claims.

42 Morange, "Retour sur le normal et le pathologique", in: Fagot-Largeault/Debru/Morange/ Han 2008, 164.

43 Giroux, “N'y a-t-il de santé que d'individu?”, in: Fagot-Largeault/Debru/Morange/Han 2008, 193.

44 Han, "La philosophie de la médecine chez Canguilhem”, in: Daled 2009, 189. 
the living is still far from being systematically addressed. If anything, a clear understanding of the links between values, phenomena, concepts - and their links to questions of being, of being human, and so on, is becoming all the more essential ${ }^{45}$.

To this I would now add the need to address Canguilhem's particular rhetorical, strategic, and conceptual strategies. Reading Canguilhem is a bit like breathing under duress: he alternates between long sentences with several clauses (sometimes more than six), and short, "machine-gunned" singleclause phrases. This is achieved to great effect in Knowledge of Life and many of his essays, and it clearly calls for a heightened attention to his rhetoric ${ }^{46}$. Moreover, for a stylist as peculiar and emphatic, it is somewhat disappointing to see the only engagement with his voice being an occasional complaint about $\operatorname{syntax}^{47}$. For this reason it seems to me that the analysis of both Canguilhem's own concepts and texts - and thus of the epistemological effort made in them - is frequently addressed in too easy and too classical a fashion, perhaps precisely the classical fashion he himself opposed. Canguilhem's argumentation through questions, through the appropriation of metaphors, through analogies and the discussion of metaphors deserves a closer and more systematic attention - all the more so given that he was philosopher who emphasized the question as the essence of philosophy ${ }^{48}$, and a historian of concepts who opposed classical history of ideas and facile or leftover positivisms (famously in his pedagogical engagement).

However, if these problems are largely avoided (and if this is indeed in the name of a certain rationalism in Canguilhem's thought), perhaps it should then not be surprising - as it is - that Bergson is almost totally absent from all these collections of essays, with the notable if unsurprising exception of Worms's essay ${ }^{49}$. Han references him once ${ }^{50}$; Dagognet presents Canguil-

45 In an earlier book, La vie humaine, Le Blanc approached many of these concerns, but it still seems to me possible to go beyond the use of normativity as the center of Canguilhem's anthropology.

46 This question becomes yet more difficult when we attempt to see when it is that Canguilhem is appropriating elements of other philosophers' and physicians' thinking while critiquing elements of their thought or overparaphrasing them. A rhetorical study of his essay on "Cell Theory" in Knowledge of Life, for example, would have to address Canguilhem's extensive dependence on Charles Singer, Etienne Guyénot and Marc Klein - if only to begin to approximate the force of his use of such secondary sources.

47 Barbara, "L'étude du vivant chez Georges Canguilhem", in: Fagot-Largeault/Debru/ Morange/Han 2008, 113.

48 Canguilhem, "Qu'est-ce que la psychologie?", in: Etudes d'histoire et de philosophie des sciences $\left({ }^{5} 1989\right) 365$.

49 Worms, "La conception du vivant comme philosophie première", in: Fagot-Largeault/Debru/ Morange/Han 2008, 142, 144.

50 Han, "La philosophie de la médecine chez Canguilhem", in: Daled 2009, 176. 
hem's thinking on life as creation without ever considering Bergson as a figure of influence on Canguilhem, who had lectured on him as early as $1942^{51}$; both Lecourt and Braunstein see Canguilhem as a critic of Bergson, perhaps because of his strong support of Georges Politzer's critique of Bergson in a publication dating to 1930. This is a remarkable evasion, all the more significant in that Canguilhem's engagement with Bergson not only determines the starting point of his Knowledge of Life, but also continues well into the Etudes d'histoire et de philosophie des sciences ${ }^{52}$ - and, not less significantly, that it goes a long way toward explaining his ontological, anthropological, and strategic conceptual efforts. Similarly, it would be tremendously useful to see further work on some figures of influence on Canguilhem that are not necessarily the most visible and immediate ones, but rather those that stand close enough but are less easily cited: figures like Merleau-Ponty, for example, who appropriated Kurt Goldstein's thought for his phenomenological project in Structure of Behavior - or even Kurt Goldstein himself, who is mentioned over and over as an influence, but whose role in Canguilhem's development has not been studied further. Mutatis mutandis, the same could be said of the absence of Husserl, whom both Foucault and David Hyder have seen as addressed by Canguilhem's thought - one might be tempted to call him a "precursor" 53 . And then one could look further (to start with the philosophers): to Heidegger, for example, whom Canguilhem avoided all his life, but whose understanding of "world" and of "projecting possibilities" comes really close to Canguilhem's understanding of the way a living human being relates to its milieu; or to Sartre, Arendt and Adorno, who in very different philosophical paradigms also sought to rethink individuality or defend the particular against oppressive universals and who offered at times highly similar critiques of the philosophical tradition. Similarly, a more definitive discussion of Canguilhem's relation to other contemporary thinkers of medicine - among them Walter Cannon, René Leriche, and even Goldstein himself - would further explain the specifically biological and physiological dimension of his thinking. Out of such studies might come a useful and current concern with the value of Canguilhem's medical and biological thought in and for a post-1945 modernity.

51 See Georges Canguilhem/Gilles Deleuze, Il Significato della vita: Letture del III capitolo dell'Evoluzione creatrice di Bergson, edited by Giuseppe Bianco (Milan 2006).

52 See the implicit address of Bergson in "Thought and the Living" in Knowledge of Life (2008) and also Etudes d'histoire et de philosophie des sciences ( $\left.{ }^{5} 1989\right), 348-354$.

53 David Hyder, "Foucault, Cavaillès, and Husserl on the Historical Epistemology of the Sciences", Perspectives on Science 11:1 (2003) 111; this claim of course follows from Michel Foucault, "Introduction" to Georges Canguilhem, The Normal and the Pathological (New York 1989) 8. 
For these reasons, and toward this goal, much remains to be done in a clarification of the influences and positive force in Canguilhem's thought and voice. However, that more can be hoped for in this direction is to the credit of the new generation of writing on Canguilhem, for it is also an indication of the breadth of possible directions this generation of readers is spreading to. There is no point, of course, in criticizing these works for not addressing every possible question; but there is one in suggesting that this plurality of readings still leave us with only an insufficient picture of Canguilhem's overall goals and system of thought. If, moreover, I am centering on three kinds of a lack - in the study of his epistemology and anthropology, in that of his rhetoric and argumentative style, and also in that of his relationship to philosophers (and physicians) whom he cites extensively or with whom his affinities are considerable -, I do so in order to further what seems to me as a major trend in these writings - the move beyond The Normal and the Pathological and toward a broader understanding of his thought and its status at a crossroads of modern philosophy, historiography, and biological thought. 